\title{
Critical Factors Influencing E-Banking Service Adoption in Jordanian Commercial Banks: A Proposed Model
}

\author{
Ihab Ali El-Qirem ${ }^{1}$ \\ ${ }^{1}$ University of Wales, Newport, UK \\ Correspondence: Ihab Ali El-Qirem, University of Wales, Newport, UK. E-mail: ihab220@yahoo.com
}

Received: October17, 2012

Accepted: November 28, 2012

Online Published: February 25, 2013

doi:10.5539/ibr.v6n3p229

URL: http://dx.doi.org/10.5539/ibr.v6n3p229

\begin{abstract}
The primary purpose of this current research is to conduct an investigation into the factors affecting the acceptance of E-Banking by clients who have access to the internet and elicit the opinion of non-internet users about E-Banking. To develop a theoretical framework model for the current study, a literature review relating to the technology acceptance model (TAM) and its various adaptations is being undertaken. The E-Banking has been chosen as an innovative service, whose possible adoption by customers will be investigated. It is believed that the successful adoption of E-Banking will be cost and convenience beneficial for all stakeholders in the financial sector. The current research model purposes an extension to the technology acceptance/ adoption models that account essential factor influence E-Banking services adoption in the Jordanian commercial banks.
\end{abstract}

Keywords: Jordanian commercial banks, E-Banking service, technology acceptance model, critical factors

\section{Introduction}

In Jordan the potentials of E-Banking service were introduced to the banking sector in mid-2002. Since then Jordanian commercial banks have been active in developing E-Baking, and M-Banking services. The banking sector in Jordan is eager to contribute to the enhancement the role of internet, mobile services in the banking transactions. Thus, the primary objectives of the current research are to investigate and measure the impact of the critical factors influences adoption of E-Banking Services.

The current research will also review available literature concerning essential factors affecting the adoption/ acceptance of E-Banking services by clients who have access to the internet and elicit the opinion of non-internet users about E-Banking. It is apparent that there is a lack of research on the issue under consideration. This has motivated the venture into this unsearched area to see whether bank account holders who have access to the internet will adopt E-Banking services.

\section{Literature Review}

\subsection{Technology Acceptance Model (TAM)}

The TAM, firstly proposed by (Davies, 1986), was conceived to predict (Fishbein \& Ajzen, 1975), and explain an individual's IT/IS acceptance (Hu, et al., 2008).

The Technology Acceptance Model (TAM) is an extension of the Theory of Reasoned Action (TRA). TRA was originally proposed by Fishbein and Ajzen in 1975 in an attempt to understand behavior and predict outcomes. TRA assumes that a person takes into account the implications of his/ her action before deciding whether or not to engage in certain behavior. It also posits that the main determinant of a person's behavior is behavior intention. The premise of TAM is that people behavioral intention to accept and actually use a certain technology is determined by two constructs namely; perceived usefulness and perceived ease of use (Davis, 1989). User's attitude and belief as proposed by TAM is perceived to be an important factor which influences the use of new technology. A person whose attitudes toward information technology are positive will have higher acceptance of the use of technology in question, compared to another person whose attitudes toward that technology are negative. Many empirical researches (e.g. Davis, et al., 1989; Agarwal \& Karahanna, 2000; Venkatesh, et al., 2003, 2007; Adams, et al., 1992; Segars \& Grover, 1993) have shown support for TAM. Thus, the technology acceptance model is generally referred to as the most influential theory in IT and Information Systems (Benbasat \& Bark, 2007). 
However, TAM has been criticized for not being able to fully reflect the specific influences of technological and usage-context factors which may alter user acceptance (Quan, et al., 2010; Davis, et al., 1989). Others (e.g. Venkatesh, et al., 2003; Chau \& Hu, 2002; Moon \& Kim, 2001; Mathieson, et al., 2001) argue that TAM requires extension and adjustment in order to comply with the specific characteristics of technology under consideration. They further point out that although the findings of TAM's application have been shown to be valid, it is not possible and feasible to apply them to the evaluation of factors affecting the voluntary acceptance of certain E-services by individual end users or customers. This is simply because TAM findings are oriented toward the adoption of technologies in companies. Thus, a number of researchers have adjusted and extended the TAM, either by adding new constructs to it, or making certain constructs redundant. Besides, Venkatesh, et al., (2003) proposed an extended TAM which unifies eight popular models and combined them to the unified theory of acceptance and use of technology to illustrate how information systems are accepted, and to highlight the factors impacting intention to use them (Venkatech, et al., 2003). The Unified theory of acceptance and use of technology (UTAUT) represents a shift from fragmented view of IT adoption or acceptance to a unified integrated single theory (Abu Shanab, et al., 2010). Kaasinen, et al., (2002) and Keat and Mohan (2004) modified the value component (from perceived usefulness) and added two components: trust and perceived ease of adoption. In a study by Quan, et al., (2010) the "attitudes" construct was removed for simplification. O'cass \& French (2003) are of the opinion that TAM should not be confined solely to the adoption of technological perspective, and that other non-computer based technological adoption should be encouraged to add a marketing flavor to the findings, and to be more specific. The researcher concluded that most of the technology acceptance models have been extensively tested in the developed countries. More specifically, the IT literature lacks technology acceptance adoption models in the Arab world. Therefore, it is vital to conduct study in terms of E-Banking services adoption in the Jordanian Commercial Banks.

\subsection{A Proposed E-Banking Service Adoption}

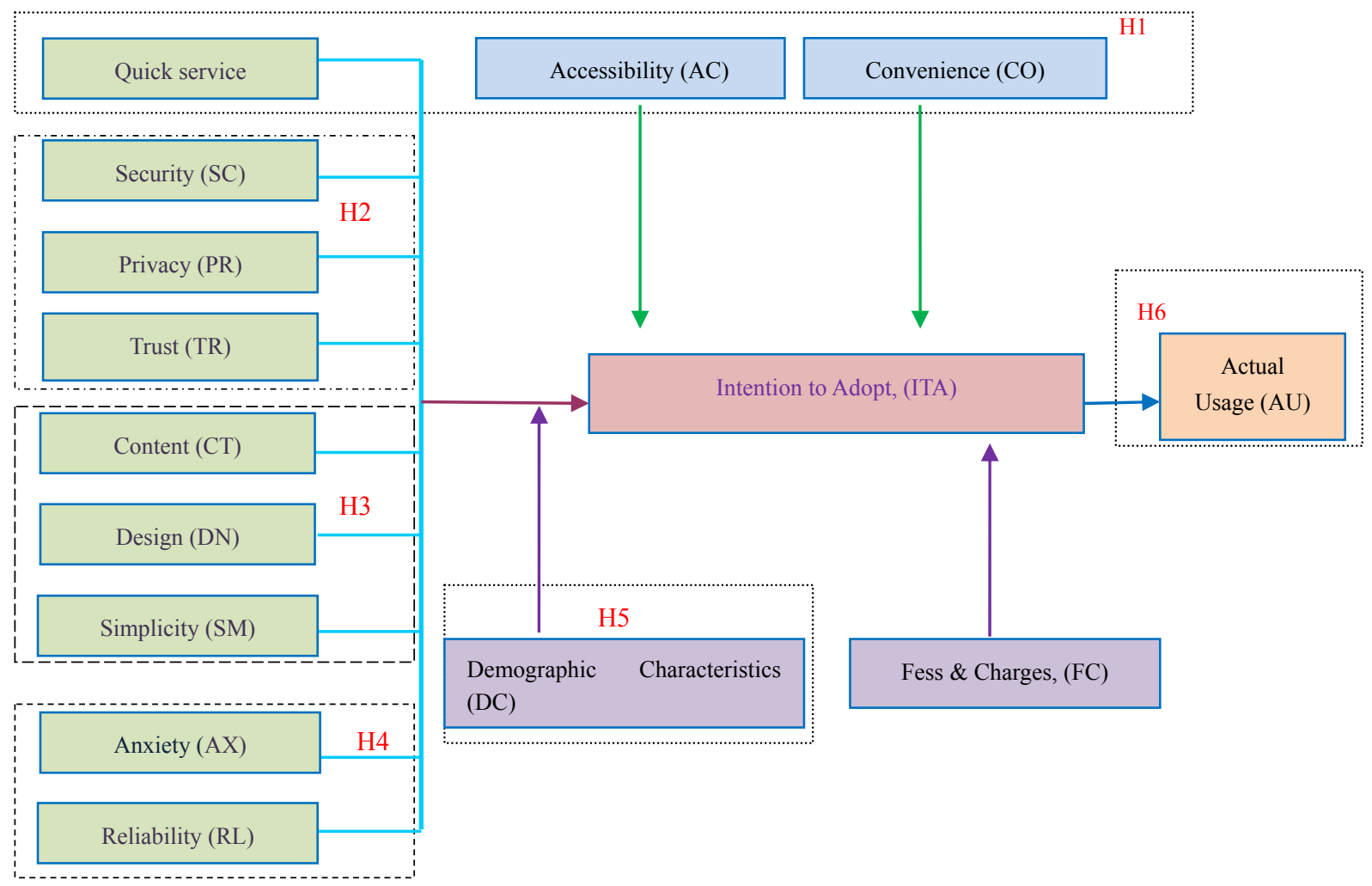

Figure 1. E-banking acceptance model

Source: Compiled in light of literature review and exerts comments (during pilot study).

Based on previous studies, a number of variables thought to be impacting the process of adoption of products and services will be discussed and later embodied in a suggested model. These variables are as follows:

\subsubsection{Convenience, Accessibility and Quick E-Service Delivery}

E-Banking provides three major advantages: convenience (Meuter et al., 2002), speedy service (Karjaluoto, et 
al., 2002), and accessibility (Al-alak \& Alnawas, 2010), compared to traditional retail banking services. Indeed, the rationale behind the establishment of E-bank Services in the first place is to enable bank account holders to conduct transactions with higher degree of convenience and speed, and to access internet banking services at all times and places. Apart from that, the accessibility of computers is perceived as a measure of relative advantage (Delvin, 1995; Ainscough \& Luckett, 1996; Daniel, 1999; Black et al., 2001; Polatoglu \& Ekin, 2001; Suganthi, et al., 2001; Gerrard \& Cunningham, 2003). Obviously, both bankers and clients would be satisfied with a service delivery that is convenient, quick and easily accessible.

\subsubsection{E-Security, Privacy and Trust}

As many bank account holders are concerned with the risk associated with E-Banking transactions, the perceived lack of financial and non-financial security is definitely a stumbling block (Jun et al., 2004). Financial security is about conveying financial information online (e.g. an account number, account statement, transfers, etc.), whereas non-financial security is related mainly to showing personal information (e.g. e-mail, telephone number, etc.). Security is defined as the protection of data against accidental or international disclosure to unauthorized persons, or unauthorized modifications or destruction (Mirza, et al., 2009). Furthermore, bank account holders often fear that their personal information might be leaked to unauthorized circles via the internet (Davis, 1993; Dumortier \& Goemans, 2001; Miyazaki \& Fernandez, 2001). Clients are also concerned about the trust ability of the E-bank's privacy policies (Gerrrard \& Cunningham, 2003). Other studies show that security and privacy are associated with trust in the sense that trust is often invoked by the academia to synchronize the issues of security, privacy, fulfillment and confidence (Lynch \& Lundguist, 1996). Indeed, numerous empirical studies have found that trust constitutes a major critical factor influencing the success of E-Banking because uncertainties often surround banking transactions over the internet (Zhang \& Tang, 2006; Chellappa, 2000; Gerrard \& Cunningham, 2003).

\subsubsection{Content, Design and Simplicity of the Banking Web Site}

According to Laukkanen, et al. (2008) consumer resistance to internet banking, especially among those who are not fully familiar with the world of internet, is mainly attributed to technical issues such as design, content and complexity not only of the web site but also the ways and means of using the site itself. Another study shows that sophisticated web site design and crowded content discourage customers from using the web site and benefit from it (Pikkarainen, et al., 2006). Earlier studies on internet banking show that the complexity or poorness of the web site design and content might deter visitors from using the services provided via such web sites (Gerrard \& Cunningham, 2003; Howcroft et al., 2002; Black et al., 2002). Simplicity is defined as the betterment of tools that enables the provider of services to deliver the benefit that satisfies an unspoken consumer's need by inserting better pictures and finding better ways of sharing to their potential customers (Piew, et al., 2010). Lau (2007) suggests that in order for a web site to be truly appealing and attractive to customers, it should be designed in such a way as to deliver the maximum benefits as perceived by end-users themselves.

\subsubsection{Anxiety and Reliability}

A study by Laukkanen, et al. (2008) reveals that psychological dimensions such as anxiety, prior beliefs, traditions and image are even greater sources of resistance to E-Banking Services than other factors. The term anxiety is most often used to describe unpleasant emotional state which characterized by tension and apprehensive (Abu Shanab et al., 2008). The anxiety motivates users to avoid condition that produce anxious feelings Reliability refers to the extent to which a user believes that he or she can rely on the E-banking service provided and feel satisfied with it (Lee \& Lin, 2005). In this sense, both reliability and anxiety might be regarded as constructs impacting the intention to use E-Banking services (Quan \& Jianxin, 2010; Piew, et al., 2010; Al-alak, 2004).

\subsubsection{Fees and Charges}

It has been empirically found that customers will be more likely to accept new technologies if the advantages gained from the use of such technologies exceed the costs incurred (Davis, 1989). Cost savings have enabled internet-based banking to offer E-Banking services at lower or no service fees, and to offer higher interest rates on interest-bearing accounts than traditional banks (Poon, 2008; Gerlanch, 2000; Jun \& Cai, 2001). Other studies (e.g. Howcroft et al., 2002; Karjaluoto, 2002; Karjaluoto, et al., 2002; Poon, 2008; Gerrard, et al., 2006; Kuisma, et al., 2007; Laukkanen, et al. 2008) argue that even though internet banking users largely perceive that the service fees are acceptable, for some non-adopters the relative advantage of internet banking may be poor due to the fact that a great deal of expenses will be incurred in buying a computer and getting online, when the costs might exceed the benefits. 


\subsubsection{Demographic Characteristics: Gender, Age, Income, and Education}

Research in the field of E-Banking suggests that demographic characteristics such as gender, age, income and education). Impact the intention to use certain E-Banking services. Wilson (2000) reveals that low income consumers would be less likely to pay for a monthly fee to subscribe to an internet service, and would be less likely to have a home computer. previous study reported that males were moved likely to adopt or accept E-Banking (Al-Qisi, 2009). However, other researchers reveal that level of education is factor capable of impacting the intention to use E-Banking services (Sathye, 1999; Matilla, et al., 2003; Laforet \& Lee, 2005; Polatoglu \& Ekin, 2001; Akinci et al., 2004; Eriksson, et al., 2005; Wan et al., 2005; Jaruwachirathanakul \& Fink, 2005).

As the main objective of the current study is to investigate the factors influencing the acceptance of E-Bankingby bank account holders in Jordan, it is expected that the positive impact of such factors as effort expectancy, convenience, accessibility, quick service delivery, security, privacy, trust and anxiety, lack of reliability, fees and charges, content, design, simplicity and demographic characteristics, on clients' intention to use E-bank statement would also determine acceptance behavior, i.e. intention to use would be positively associated with acceptance behavior.

\subsubsection{Behavioral Intention}

Behavioral intention to adopt/accept E-Banking services measures a user's relative strength of intention to perform a behavior (Fishbein, Ajzen, 1975). It is an indicator of a person's motivation to perform specific behavior. Behavior intention is considered as the antecedent of actual behavior.

\subsubsection{Actual Usage}

(Davis, 1985) proposed that system use is a response that be explained by user motivation which in turn is directly influenced by external variables consisting of the actual system features and capabilities. Davis considered that the actual use of a system is a behavior. Actual use of behavioral usage is usually measured by amount of time using, frequency of use, actual number of usage and diversity of usage.

Research's Hypothesis

This model has strong behavioral elements assume that when banks users form behavioral intention to adopt or accept such technology such as E-bankingthey will be free to act without imitation. Thus, the researcher hypothesized that the intention to adopt/accept E- bankingis a major determinant of whether the bank's user (client) will actually use or reject this technology.

Based on the research's model, the author suggests the following hypotheses:

H1: There will be a positive significant relationship between convenience, accessibility and quick service delivery and intention to adopt E-banking.

H2: There will be a positive significant relationship between security, privacy, and trust and intention to adopt. E-Banking.

H3: There will be a positive significant relationship between content, design, and simplicity and intention to adopt E-Banking.

H4: There will be a positive significant relationship between anxiety and reliability and intention to adopt Ebanking.

H5: There will be a positive significant relationship between fees and changes and intention to adopt E-Banking.

H6: There will be a positive significant relationship between intention to adopt a E-bankingnd the actual usage.

H7: The influence of convenience, accessibility, and quick delivery service on behavioral intention to adopt E-banking will be moderated by experience, gender, and age, such that the effect will be stronger for men and particularly for younger men at early stages of experience.

\section{Methodology and Data}

\subsection{Population, Sampling and Instrument}

The population of the study will be made up of all bank account holders who make use of E-Banking in Jordan. A convenient sample of 3000 respondents will be selected to obtain the required primary data. The study's instrument will be a self-administered questionnaire that will be developed and employed to achieve the objectives of the current study. To improve the structure design and content of the study's instrument, a pilot study will be carried out. The questionnaire will be revised in the light of comments received from 30 experts, 
who include 15 academicians and 15 bank managers. The questionnaire will consist of two sections. Section 1 covers questions on respondent's profile, and Section 2 focuses on the variables that are believed to impact customer intention to adopt E-Banking.

Respondents will be asked to rank their level of agreement based on a 5-point Likert scale, ranging from ' 1 ' (strongly disagree) to ' 5 ' (strongly agree). The response rate is expected to be around $90.8 \%$. The process of distributing the questionnaire will be drop-off approach (Aaker et al., 2004). On the basis of the logic of this method, the researchers will deliver the questionnaire to clients who categorically state that they have experience with E-Banking, after explaining to them the purpose of the study, the required procedures to fill out the questionnaire and answering any question with regard to any of the questionnaire's statement.

\section{Conclusion}

The purpose of this research is to conduct an investigation into the essential factors affecting the behavioral intention to adopt or accept of E-Banking service in the Jordanian Commercial Banks. The proposed model posits that Effort expectancy, convenience, accessibility quick service delivery, security, privacy, trust, content, design and simplicity of the banking website as well as anxiety, lack of reliability, fees and charges and E-service quality have a direct impact on the behavioral intention to adopt financial services. At the same time this research suggests a direct impact of the behavioral intention on the actual usage of the E-Banking service. The literature review indicated that TAM models were extensively used to explain the intention to accept and use specific technology in the developed countries more than Arab world. While some researches have been used TAM models in Arab business environment, to date very little research has been done to address E-Banking services adoption in Jordan.

\section{References}

Aaker, D., Kumar, V., \& Days, G. (2004). Marketing Research (8th ed.). New York: John Wiley \& Sons.

Abu, S., et al. (2010). Internet Banking and Customer's Acceptance in Jordan: The Unified Model's perspective. Communications of Association for Information Systems, 26(23).

Adams, D., Nelson, R., \& Todd, P. (1992). Perceived usefulness, ease of use, and usage of information technology. MIS Quarterly, 16, 227-247. http://dx.doi.org/10.2307/249577

Agarwal, R., \& Karahanna, E. (2000). Time flies when you're having fun: cognitive absorption and beliefs about information technology usage. MIS Quarterly, 24, 665-694. http://dx.doi.org/10.2307/249577

Ainscough, T., \& Luckett, M. (1996). The internet for the rest of us: Marketing on the World Wide Web. Journal of Consumer Marketing, 3(2), 36-47. http://dx.doi.org/10.1108/07363769610115393

Akinci, S., Aksoy, S., \& Atilgan, E. (2004). Adoption of internet banking among sophisticated consumer segments in an advanced developing country. International Journal of Bank Marketing, 22(3), 212-232. http://dx.doi.org/10.1108/02652320410530322

Akour, I., et al. (2006). An Exploratory Analysis of Culture, Perceived Ease of Use, Perceived Usefulness, and Internet Acceptance: The Case of Jordan. Journal of Internet Commerce, 5(3). http://dx.doi.org/10.1300/J179v05n03_04

Aldajani, D. M. (2011). Critical Analysis of E-Commerce use by Jordanian Travel Agents. (Ph.D thesis). The University of Leeds, Leeds University Business School.

Al-Qisi, K. I. (2009). Analyzing the use of UTAUT model in Explaining an Online Behavior, Internet Banking Adoption. (PhD thesis). Brunel University, UK.

Benbasat, I., \& Barki, H. (2007). Quo Vadis, TAM? Journal of Association for Information Systems, 8(4), No. 3.

Buhalis, D., \& O’Conner, P. (2005). Information Communication Technology Revolution. Zing Tourism, Tourism Recreation Research, 3(3), 7-16.

Chau, P., \& Hu, P. (2002). Investigating healthcare professionals' decisions accept telemedicine technology: an empirical test of competencies theories. Information \& Management, 39, 297-311. http://dx.doi.org/10.1016/S0378-7206(01)00098-2

Chellapa, R. (2000). Consumers trust in electronic commerce transactions: the role of perceived privacy and perceived security. Ebizlab Working Paper, Marshall School of Business, University of South California, Los Angeles, CA. Emory University Atlanta, GA 30322-2710. Retrieved 14 February 2002 from http://www.bus.emory.edu/ram/papers/sec-priv.pdf 
Chong, A., Ooi, K., Lin, B., \& Tan, B. (2010). Online banking adoption: an empirical analysis. International Journal of Bank Marketing, 28(4), 267-287. http://dx.doi.org/10.1108/02652321011054963

Daniel, E. (1999). Provision of electronic banking in the UK and the Republic of Ireland. International Journal of Bank Marketing, 179(2), 72-82. http://dx.doi.org/10.1108/02652329910258934

Davis, F. (1989). Perceived Usefulness, Perceived Ease of Use, and User Acceptance of Information Technology. MIS Quarterly, 13(3), 318-339. http://dx.doi.org/10.2307/249008

Davis, F. (1993). User acceptance of information technology: system characteristics, user perceptions and behavioral impacts. International Journal of Man - Machine Studies, 38, 475-487. http://dx.doi.org/10.1006/imms.1993.1022

Davis, F., Bagozzi, R., \& Warshaw, P. (1989). User Acceptance of Computer Technology: A Comparison of Two Theoretical Models. Management Science, 35(8), 982-1003. http://dx.doi.org/10.1287/mnsc.35.8.982

Dodds, R., Graci, S., \& Holmes, M. (2010). Does the tourist care? Journal of Sustainable Tourism, 18, 207-222. http://dx.doi.org/10.1080/09669580903215162

Dumortier, J., \& Goemans, C. (2000). Data Privacy and Standardization. Discussion paper prepared for the CEN/ISSS Open Seminar on Data Protection, Brussels, 23-24 March.

Eisingerich, A., \& Bell, S. (2006). Relationship marketing in the financial services industries: The importance of customer education, participation and problem management for customer loyalty. Journal of Financial Services Marketing, 10(4), 86-97. http://dx.doi.org/10.1057/palgrave.fsm.4760022

Eriksson, K., Kerem, K., \& Nilson, D. (2005). Customer acceptance of internet banking in Estonia. International Journal of Bank Marketing, 23(2), 200-216. http://dx.doi.org/10.1108/02652320510584412

Fishbien, M., \& Ajzen, I. (1975). Belief, Attitude, Intention and behavior: An Introduction to Theory and Research. Reading, MA: Addison - Wesley.

Gerrard, P., \& Cunningham, J. (2003). The diffusion of internet banking among Singapore consumers. International Journal of Bank Marketing, 21(1), 16-28. http://dx.doi.org/10.1108/02652320310457776

Grerlach, D. (2000). Put your money where your mouse is. PC World, March, 191-199.

Harmon, R. (2003). Marketing Information Systems. Encyclopedia of Information Systems, 3, 138-139.

Ho, C., \& Lee, Y. (2006). The Development of E-travel Service Quality Scale. Tourism Management, 28, 1434-1445. http://dx.doi.org/10.1016/j.tourman.2006.12.002

Howcroft, B., Hamilton, R., \& Hewer, P. (2002). Consumer attitude and the usage and adoption of home-based banking in the United Kingdom. International Journal of Bank Marketing, 20(3), 111-121. http://dx.doi.org/10.1108/02652320210424205

Hu, H. J., Taegoo, K., \& Rob, L. (2008). A Comparison of Competing Theoretical Models for understanding acceptance behavior of information systems in upscale Hotels. International Journal of Hospitality Management.

Jaruwachirathanakul, B., \& Fink, D. (2005). Internet banking adoption strategies for a developing country: the case of Thailand. Internet Research, 15(3), 295-311. http://dx.doi.org/10.1108/10662240510602708

Jun, M., \& Cai, S. (2001). The key determinants of internet banking service quality. Journal of Bank Marketing, 19(7), 276-291. http://dx.doi.org/10.1108/02652320110409825

Jun, M., Yang, Z. C., \& Kim, D. (2004). Customers' perceptions of online retailing service quality and their satisfaction. Int. J. Qual. Reliabil. Manage, 21, 817-840. http://dx.doi.org/10.1108/02656710410551728

Kaasinen, V., Ikonen, A., Ahonen, V., Anttila, M., Luoma, M., \& Södergård, R. (2002). Products and Services for Personal Navigation. Classification from the Users' Point of View, Publications of the NAVI Programme. Retrieved 4.1. 2005 from http://www.vtt.fi/virtual/navi

Karjaluoto, H. (2002). Selection criteria for a mode of bill payment. International Journal of Retail and Distribution Management, 30(6), 331-339. http://dx.doi.org/10.1108/09590550210429540

Karjaluoto, H., Mattilam, M., \& Pento, T. (2002). Factors underlying attitude formation towards online banking in Finland. Int. J. Bank Market, 20, 261-272. http://dx.doi.org/10.1108/02652320210446724

Keat, T., \& Mohan, A. (2004). Integration of TAM based electronic commerce models or trust. J. Am. Acad. Bus., 5, 404-410. 
Kimery, K., \& McCard, M. (2002). Third-party assurance: mapping the road to trust in e-retailing. Journal of Information Technology Theory and Application, 4(2), 63-82.

Laforet, S., \& Li, X. (2005). Consumers' attitudes towards online and mobile banking in China. International Journal of bank Marketing, 23(5), 362-380. http://dx.doi.org/10.1108/02652320510629250

Laukkanen, P., Sinkonnen, S., \& Laukkanen, T. (2008). Consumer resistance to internet banking: postponers, opponents and rejecters. International journal of Bank Marketing, 26(6), 440-455. http://dx.doi.org/10.1108/02652320810902451

Lynch, D., \& Lundquist, L. (1996). Digital Money: The new era of internet commerce. New York: John Wiley \& sons.

Mathesion, E., Peacock, E., \& Chin, W. (2001). Extending the technology acceptance model: the influence of perceived user resources. DATA BASE for advances in Information Systems, 32, 86-112. http://dx.doi.org/10.1145/506724.506730

Matilla, M., Karjaluoto, H., \& Pento, T. (2003). Internet banking adoption among mature customers: early majority or laggards? Journal of Services Marketing, 17(5), 514-528. http://dx.doi.org/10.1108/08876040310486294

Meuter, M., Ostrom, A., Roundtree, R., \& Bitner, M. (2000). Self-service technologies: Understanding customer satisfaction with technology-based service encounters. J. Market, 64, 50-64. http://dx.doi.org/10.1509/jmkg.64.3.50.18024

Moon, J., \& Kim, Y. (2001). Extending the TAM for a World - Wide - Web context. Information \& Management, 38, 217-230. http://dx.doi.org/10.1016/S0378-7206(00)00061-6

Nyeck, S., Ladhari, R., Morales, M., \& Pons, F. (2002). Assessment of SERVQUAL Validity: An Evaluation of 10 Years of the Measurement of Service Quality. Proceedings of the $31^{\text {st }}$ European Marketing Academy Conference, EMAC, May 28-31, Braga, Portugal.

O'Cass, A., \& French, T. (2003). Webretailing adoption: exploring the nature of internet users' Webretailing behaviour. Journal of Retailing and Consumer Services, 10, 81-94. http://dx.doi.org/10.1016/S0969-6989(02)00004-8

Ong, H., \& Cheng, M. (2003). Success factor in e-channels: the Malaysian banking scenario. International Journal of Bank Marketing, 21(6), 369-377. http://dx.doi.org/10.1108/02652320310498519

Pikkarainen, K., Pikkarainen, T., Karjaluoto, H., \& Pahnila, S. (2006). The measurement of end-user computer satisfaction of online banking services: empirical from Finland. International Journal of Bank Marketing, 24(3), 158-172. http://dx.doi.org/10.1108/02652320610659012

Polatoglu, V., \& Ekin, S. (2001). An empirical investigation of the Turkish consumers' acceptance on internet banking services. International Journal of Bank Marketing, 19(4), 156-165. http://dx.doi.org/10.1108/02652320110392527

Segars, A., \& Grover, V. (1993). Re-examining perceived ease of use and usefulness: a confirmatory factor analysis. MIS Quarterly, 17, 517-525. http://dx.doi.org/10.2307/249590

Suganthi, S., Balachander, K., \& Balachander, S. (2001). Internet banking patronage: an empirical investigation of Malaysia. Journal of Internet Banking and Commerce, 6(1). Retrieved from http://www.arraydev.com/commerce/JIBC/0103_01.htm

Venkatesh, V., Morris, M., \& Davis, G. (2003). User acceptance of information technology: Toward a Unified View. MIS Quarterly, 227, 425-427.

Venkatesh, V., Davis, F., \& Morris, M. (2007). Dead or alive? The development, trajectory and future of technology adoption research. Journal of the Association for Information Systems, 8, 267-286.

Wan, W., Luk, C., \& Chow, C. (2005). Consumers' adoption of banking channels in Hong Kong. International Journal of Bank Marketing, 23(3), 255-272. http://dx.doi.org/10.1108/02652320510591711

Wilson, E. (2000). Closing the Digital Divide: An Initial Review: Briefing the President, May, The internet Policy Institute, Washington, DC. Retrieved http://www.internetpolicy.org/briefing/ErnestWilson0700.html

Yaseen, S. (2011). Critical Factors Influencing Green IT Adoption: A Proposed Model. International Journal of Arts \& Sciences (IJAS) Conference for Academic Disciplines, Ryerson Uniersity, Toronto, Canada. 
Yaseen, S., \& Suleiman, Z. (2010). Exploring Critical Determinants in Developing Mobile Commerce Technology. American Journal of Applied Science, 7(1). http://dx.doi.org/10.3844/ajassp.2010.120-.126

Zhang, X., \& Tang, Y. (2006). Customer perceived e-service quality in online shopping. (M.A. Thesis). Lulea University of Technology.

\section{Notes}

Note 1. http://teletimesinternational.com/middleeast/3109/zain-jordan-signs-up-4500-for-mobilE-Banking-service

Note 2. http://www.internetworldstats.com/me/jo.htm 